\title{
A survey of in-vitro and in-vivo effects of steroids on melanoma growth and its implication on the nature of the disease
}

\author{
Ramaraj P* \\ Department of Biochemistry, Kirksville College of Osteopathic Medicine, A.T.Still University, Kirksville, Missouri, USA
}

Melanoma, a fatal form of skin cancer accounts for less than $2 \%$ of skin cancer, but is responsible for $75 \%$ death due to skin cancer [1]. UV rays in the Sun is believed to be responsible for $90 \%$ of melanoma incidence [2], with only $10 \%$ inherited in the family. Epidemiological studies showed that mortality rate was higher in males than in females [3]. Current targeted therapy and immuno-therapy are accompanied by serious side-effects such as endocrinopathies and other allergic and autoimmune disorders $[4,5]$. This situation warrants an understanding of the fundamental nature of the disease before developing any treatment. At this juncture, a survey of in-vitro and in-vivo effects of steroids on melanoma growth [6] provided a basis for the nature of this disease.

Apart from being the largest organ in the body, skin is also an endocrine gland which secrets various hormones [7,8]. Skin has an analogous hypothalamus, pituitary and adrenal axis with the production of POMC, ACTH and glucocorticoid steroidogenesis [9]. Studies showed that local production of hormones in the skin not only influenced regionally, but also affected systemically [10]. In addition, skin is also the site for production of sex steroids such as testosterone and estrogen. Sex steroids such as progesterone, estrogen and androgens are essential for a healthy skin [11]. In fact, melanocyte, which produces melanin pigment in skin is under the influence of melanocyte stimulating hormone (MSH) from pituitary [8]. Hence, these observations raise the question whether melanoma is a hormone dependent cancer like breast, endometrial and prostate cancers. So far UV rays from the sun and other radiations are considered as the major cause for melanoma, but not hormones as the cause for this disease. However, various in-vitro experiments showed that steroid hormones decreased melanoma cell growth $[12,13]$. Our lab also showed that progesterone, a female sex hormone inhibited melanoma cell growth significantly in-vitro [14,15]. Other researchers, Fang et al. [16] from China also showed the effect of progesterone on melanoma cell growth in-vitro. Later the study was repeated by Moroni et al. [17] from Italy using progesterone concentration up to $1000 \mu \mathrm{M}$ and showed the inhibition of melanoma cell growth. Earlier Kanda and Watanbe [18] from Japan also demonstrated the inhibitory effect of progesterone on melanoma cell growth. So, these in-vitro studies suggested that progesterone might regulate melanoma cell growth. This raised the question whether there were in-vivo evidences for the effect of progesterone on melanoma. To that end, previous clinical studies showed that menstruating females were better protected in melanoma than post-menopausal women and men of any age $[19,20]$. But these clinical studies were not correlated with steroid status in females and did not demonstrate any direct effect of steroids on melanoma cells. In addition, there were in-vivo experiments with small animals where steroids were used to treat melanoma [21,22]. So, in-vitro and in-vivo studies suggested that melanoma could be a hormone responsive cancer, where hormones were needed for survival in melanoma. Progesterone could be the steroid hormone protecting menstruating females in melanoma, as progesterone level peaked in menstruating females between $1000-1500 \mathrm{ng} / \mathrm{dL}$ [23]. Whereas, progesterone level in postmenopausal women ranged between $20-100 \mathrm{ng} / \mathrm{dL}$ [23]. Further, epidemiological data showed that mortality rate was higher in males than in females [3]. Progesterone level in males ranged between 27 $90 \mathrm{ng} / \mathrm{dl}$ and its function was not known in males. So, the two groups which were not protected in melanoma had low progesterone level in circulation. But, this observation could be a mere coincidence between progesterone and melanoma growth. A valid biochemical evidence mediated by a biomolecule is needed to make the connection between progesterone and melanoma growth. In this context, our further invitro research revealed that progesterone action was mediated by a specific suppression of pro-inflammatory cytokine IL-8 [24]. When IL-8 level was decreased, melanoma cell growth was decreased. There were several in-vitro and in-vivo studies connecting IL-8 level with melanoma growth such as IL-8 acting as an autocrine growth factor for melanoma cell growth and IL-8 conditional expression increased melanoma growth and metastasis in a mouse model $[25,26]$.

In summary, in-vitro and in-vivo animal studies along with clinical and epidemiological studies suggested that melanoma could be a hormone (progesterone) responsive cancer and that progesterone action was mediated by a suppression of pro-inflammatory cytokine IL8. IL-8 in turn was shown to regulate melanoma cell growth. So, IL-8 could be a mediator molecule of progesterone action on melanoma growth, providing a biochemical basis for previous clinical findings that menstruating females (with a peak progesterone level of 1000-1500 $\mathrm{ng} / \mathrm{dL}$ ) were better protected in melanoma. Understanding this basic nature of melanoma is important in developing a future treatment for melanoma.

\section{References}

1. Gray-Schopfer V, Wellbrock C, Marais R (2007) Melanoma biology and new targeted therapy. Nature 445: 851-857. [Crossref]

2. Rass K, Reichrath J (2008) UV damage and DNA repair in malignant melanoma and nonmelanoma skin cancer. Adv Exp Med Biol 624: 162-178. [Crossref]

${ }^{\star}$ Correspondence to: Pandurangan Ramaraj, Department of Biochemistry, Kirksville College of Osteopathic Medicine, A.T.Still University, Kirksville, Missouri, USA, E-mail: pramaraj@atsu.edu

Received: May 01, 2019; Accepted: May 24, 2019; Published: May 27, 2019 
3. http://seer.cancer.gov/statfacts/html/melan.html.

4. Ladarola C, Croce L, Quaquarini E, Teragni C, Pinto S, et al. (2019) Nivolumab induced thyroid dysfunction: Unusual clinical presentation and challenging diagnosis. Frontiers in Endocrinlology 9: 813

5. Chang LS, Barroso-Sousa R, Tolaney SM, Hodi FS, Kaiser UB, et al. (2019) Endocrine toxicity of cancer immunotherapy targeting immune checkpoints. Endo Rev 40: 17-65.

6. Ramaraj P (2019) Hormonal regulation of cutaneous melanoma - A brief review of invivo and in-vitro studies and it clinical implication, Chapter in: Cutaneous melanoma, edited by: Pawel Pietkiewicz, ISBN 978-1-78984-140-4, Intech open, Rijeka, Croatia,

7. Zouboulis CC (2004) The human skin as a hormone target and an endocrine gland. Hormones (Athens) 3: 9-26. [Crossref]

8. Slominski A, Wortsman J (2000) Neuroendocrinology of the skin. Endocr Rev 21: 457487. [Crossref]

9. Slominski A, Zbytek B, Nikolakis G, Manna PR, Skobowiat C, et al. (2013) Steroidogenesis in the skin: implications for local immune functions. J Steroid Biochem Mol Biol 137: 107-123. [Crossref]

10. Slominski A, Wortsman J (2003) Self-regulated endocrine systems in the skin. Minerva Endocrinol 28: 135-143. [Crossref]

11. Zouboulis CC, Chen WC, Thornton MJ, Qin K, Rosenfield R (2007) Sexual hormones in human skin. Horm Metab Res 39: 85-95. [Crossref]

12. Ghosh R, Ott AM, Seetharam D, Slaga TJ, Kumar AP, et al. (2003) Cell cycle block and apoptosis induction in a human melanoma cell line following treatment with 2-methoxyostradiol: therapeutic implications? Melanoma Res 13: 119-127.

13. Disorbo DM, McNulty B, Nathanson L (1983) In vitro growth inhibition of human malignant melanoma cells by glucocorticoids. Cancer Res 43: 2664-2667.

14. Ramaraj P, Cox JL1 (2014) In vitro effect of progesterone on human melanoma (BLM) cell growth. Int J Clin Exp Med 7: 3941-3953. [Crossref]

15. Leder DC, Brown JR, Ramaraj P (2015) In-Vitro Rescue and Recovery Studies of Human Melanoma (BLM) Cell Growth, Adhesion and Migration Functions After Treatment with Progesterone. Int J Clin Exp Med 8: 12275-12285.
16. Fang X, Zhang X, Zhou M, Li J (2010) Effects of progesterone on the growth regulation in classical progesterone receptor-negative malignant melanoma cells. J Huazhong Univ Sci. Technolog Med Sci 30: 231-234.

17. Moroni G, Gaziano R, Bue C, Agostini M, Perno CF, et al. (2015) Progesterone and melanoma cells: An old story suspended between life and death. J Steroids Horm Sci S13: 158 .

18. Kanda N, Watanbe S (2001) 17-estradiol, progesterone and dihydrotestosterone suppress the growth of human melanoma by inhibiting Interleukin- 8 production. $J$ Invest Dermatol 117: 274-283.

19. Kemeny MM, Busch E, Stewart AK, Menck HR (1998) Superior survival of young women with malignant melanoma. Am J Surg 175: 437-444. [Crossref]

20. Miller JG, Mac Neil S (1997) Gender and cutaneous melanoma. Br J Dermatol 136 657-665. [Crossref]

21. Feucht KA, Walker MJ, Das Gupta TK, Beattie CW (1988) Effect of 17-oestradiol on the growth of estrogen receptor positive human melanoma in vitro and in athymic mice. Cancer Res 48: 7093-7101.

22. Morvillo V, Luthy IA, Bravo AI, Capurro MI, Donaldson M, et al. (1995) Atypica androgen receptor in the human melanoma cell line IIB-MEL-J. Pigment Cell Res 8: 135-141. [Crossref]

23. Haggstrom M (2014) Reference ranges for estradiol, progesterone, luteinizing hormone and follicle-stimulating hormone during the menstrual cycle. Wiki Journal of Medicine 1: 1

24. Miller A, Fulcher A, Dock P, Ramaraj P (2018) Biochemical basis of protection by progesterone in melanoma based on curcumin pre-treatment of human melanoma cell models. Endo Hom

25. Schadendorf D, Moller A, Algermissen B, Worm M, Sticherling M, et al. (1993) IL-8 produced by human malignant melanoma cells in vitro is an essential autocrine growth factor. J Immunol 151: 2667-2675

26. Singh RK, Gutman M, Radinsky R, Bucana CD, Fidler IJ, et al. (1994) Expression of interleukin 8 correlates with the metastatic potential of human melanoma cells in nude mice. Cancer Res 54: 3242-3247.

Copyright: (2019 Ramaraj P. This is an open-access article distributed under the terms of the Creative Commons Attribution License, which permits unrestricted use, distribution, and reproduction in any medium, provided the original author and source are credited. 